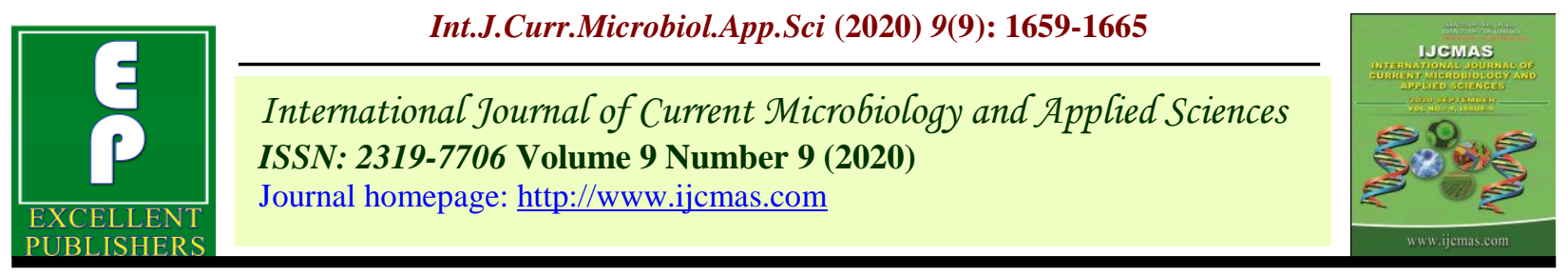

Original Research Article

https://doi.org/10.20546/ijcmas.2020.909.206

\title{
Management of Sheath Blight and Blast Disease of Rice
}

\author{
Rajiv Kumar* \\ Krishi Vigyan Kendra, Palamu-822102, Birsa Agricultural University, \\ Ranchi, Jharkhand, India \\ *Corresponding author
}

\section{A B S T R A C T}

Keywords

Rice, Socio-

economic status,

Blast and sheath

blight management

Article Info

Accepted:

15 August 2020

Available Online:

10 September 2020
The study was conducted in Palamu district of Jharkhand to know the socioeconomic status of farmers. They were categorized in three groups i.e. small ,medium and large farmers which were differ from each other with regard to socio -economic factors and found that 54 per cent rice growers has medium level of knowledge . Most of the small category farmers have high technological gap of lack of technological guidance $(67.73 \%)$ followed by lack of money $(63.77 \%)$. The different sub practices grouped into 6 categories and found that plant protection measures is one of the major concerns for technological gap. $1^{\text {st }}$ spray with Carbendazim $(0.2 \%) \& 2^{\text {nd }}$ spray with Propiconazole $(0.1 \%)$ was effective in reducing the incidence of both blast and sheath blight diseases and increased the grain yields.

\section{Introduction}

Rice is staple food of humid areas of Assam, Manipur, West Bengal, Orissa, Jharkhand, Bihar, Eastern U.P. and South India. It prefers low lying and water logged areas where none of the other cereals could be grown. However, evolution of new plant type has made it possible to grow rice even in areas having relatively low rainfall and lighter soil types like Punjab, Haryana, and Western U.P. etc. It has also observed that the yield is much higher in newly acquired areas than the traditional rice growing areas which could be accounted for evolution of high yielding dwarf plant types, better soil and water management practices and efficient nutrient management schedule etc. Rice is one of the major crops of Jharkhand and occupies 7.17 lakh hectares contributing 10.40 lakh tones grain to the state and has direct effect on the economy of the farmers of the state. The average yield of the Jharkhand (1.45 tons/ha) is below the national demonstration yield (1.9 t/ha). To know the adoption gap present study was made with the objectives include to study the knowledge level of rice grower about improved practices; To determine the technological gap; And also to identify the constraints responsible for low yield. Sheath blight of disease of rice occurring in all the rice growing regions of the world causing 
conice caused by Rhizoctonia solani is another most important siderable loss in grain yield (Savary et al., 2006). Annual yield losses up to $40 \%$ were reported with sheath blight under optimum conditions of disease development (Zhong et al., 2007).

The importance of these diseases in Karnataka has increased in recent years and appeared in severe form and has caused considerable losses in grain yields during Kharif 2011 and 2012 in hill zone of Uttara Kannada district.

Many epidemics of rice diseases have occurred resulting in threat to food security (Thind, 2002). Currently these diseases are being managed by application of chemical fungicides such as carbendazim, mancozeb, tricyclozole, propiconazole etc. and many workers have reported carbendazim as the most effective against blast and sheath blight diseases (Narayanaprasad et al., 2011). Though same chemical fungicides are being widely used to control blast and sheath blight diseases, but continuous over use of fungicides leaves harmful residues causing environmental pollution and results in the development of resistance in the plant pathogens. As such experimenting new molecule of fungicides is a continuous process and use single molecule to multiple diseases is yet another challenge to effectively reduce the disease over time and reduce the cost of the grower. Therefore, experiments were carried out to know the effectiveness of new chemical for management of blast and sheath blight diseases of Rice.

Blast disease of rice caused by Magnaporthe grisea B.Couch sp. Nov. is one of the major constraints to rice production. Rice blast is more important in upland and rainfed low land ecosystems than in other ecologies. This disease is still remains one among the most serious biotic constraints to rice yield in south
Asia. It has been estimated that about sixty per cent of the total yield was affected by blast and approximately 6.5 million tons of Rice lost in Thailand (Disthaporn, 1994). Resurgence of resistant strains of M.grisea is a well known phenomenon and several research articles have been well documented (Lalithakumari and Annamali 1990).

\section{Materials and Methods}

The present study was carried out in Palamu district of Jharkhand. Palamu district consists of 21 blocks. The survey were conducted in two blocks (Chainpur \& Chatarpur) in two stages and categorized in three categories viz. small, medium and large farmers and into three categories on the basis of adoption index(A.I.)viz. low adopter(0-20 \% A.I.), medium adopter(21-40\% A.I.) and higher adopter(above $\quad 40 \% \quad$ A.I.).Based on technological gap analysis on farm trial was conducted.

To know the efficacy of fungicides on severity of sheath blight and blast disease experiment was conducted on farmer's field of the Palamu district. Twenty five days old seedlings of a susceptible rice variety (Swarna) were planted in a randomized block design with four treatments and ten replications and the crop was raised following recommended package of practices.

The first spray was given immediately after the onset of the disease and subsequent spray at 20 days interval. Percent Disease Index (PDI) for blast and sheath blight (before and after sprays) was calculated by using the formula (Wheeler, 1969) and yield of rice $(\mathrm{q} / \mathrm{ha})$ was recorded and analysis was done using standard statistical methods. In each plot 10 plants were randomly selected and graded for blast and sheath blight diseases using 0-9 scale as given by Anonymous, 2002. 


\section{Results and Discussion}

\section{Socio-economic factors}

The frequency distribution of knowledge level, categorized into three categories, shows that 54 per cent rice growers has medium level of knowledge. The different sub practices grouped into 6 categories and found that plant protection measures is one of the major concerns for technological gap. Most of the small category farmers have high technological gap.

The first and foremost barrier in the technological gap is lack of technological guidance $(67.73 \%)$ followed by lack of money (65.77\%) and is in agreement with findings of Sharma et al., (2007) (Table 1-3).

\section{Percent disease intensity (PDI)}

The leaf blast and sheath blight diseases were observed in the early stages of the crop growth and observations were recorded against blast and sheath blight disease in rice is presented in Table 4. The treatments differed significantly for the incidence of diseases and yield of rice at the later stages of the crop growth. Per cent disease intensity was recorded in all the treatments before spray and results revealed that there is significant difference among the treatments where, the PDI ranged between 10.43 and
2.54 per cent for leaf blast incidence. While, it was ranged from 13.55 to 7.12 per cent for sheath blight disease incidence. However, after $2^{\text {nd }}$ sprays at 20 days interval significant variation was observed in blast disease occurrence between the treatments. The results revealed that, $1^{\text {st }}$ spray with Carbendazim 50\% WP $(0.2 \%) \& 2^{\text {nd }}$ spray with Propiconazole $(0.1 \%)$ has considerably reduced the blast incidence $(3.12 \%)$ followed by Seed treatment with Carbendazim (0.2\%) followed by two spray with Propiconazole $(0.1 \%)$ (TO3) However, Seed treatment with Carbendazim $(0.2 \%)$ and two spray with Mancozeb $(0.3 \%)$ (TO2) were found to be the next best effective treatments vis-a vis farmers practice (TO1) which has recorded maximum blast incidence. There was significant difference among the treatments in reducing the sheath blight and panicle blast incidence and highest sheath blight $(20.78 \%)$ and panicle blast $(14.37 \%)$ incidence was recorded in farmers practice (TO1).

\section{Yield}

The trend in reduction of two diseases of rice has reflected in the yields (Table 4). The maximum yield $34.40 \mathrm{~g} / \mathrm{h}$ was recorded in the (TO4) plots. This is found to be on par with other treatments, while treatments TO3 and $\mathrm{TO} 2$ were the next best effective treatments in obtaining the yields.

Table.1 Knowledge level of recommended practices of rice production of different categories of rice grower

\begin{tabular}{|c|c|c|c|c|c|c|c|}
\hline \multirow[t]{3}{*}{ SI.No. } & \multirow{3}{*}{$\begin{array}{l}\text { Categories of } \\
\text { farmers }\end{array}$} & \multicolumn{6}{|c|}{ Knowledge level } \\
\hline & & \multicolumn{2}{|c|}{ Low } & \multicolumn{2}{|c|}{ Medium } & \multicolumn{2}{|c|}{ High } \\
\hline & & Frequency & Percentage & Frequency & Percentage & Frequency & Percentage \\
\hline 1 & Small(80) & 27 & 33.75 & 36 & 45.00 & 17 & 21.25 \\
\hline 2 & Medium (50) & 7 & 14.00 & 33 & 66.00 & 10 & 20.00 \\
\hline 3 & Big (20) & 3 & 15.00 & 12 & 60.00 & 5 & 25.00 \\
\hline Total & & 37 & 24.67 & 81 & 54.00 & 32 & 21.34 \\
\hline \multicolumn{2}{|l|}{ Rank } & \multicolumn{2}{|c|}{ II } & \multicolumn{2}{|c|}{ I } & \multicolumn{2}{|c|}{ III } \\
\hline
\end{tabular}


Table.2 Extent of technological gap of package of practices of rice (percentage)

\begin{tabular}{|c|c|c|c|c|c|c|c|c|c|c|c|c|c|}
\hline \multirow{3}{*}{$\begin{array}{l}\text { Sl. } \\
\text { No. }\end{array}$} & \multirow{3}{*}{$\begin{array}{l}\text { Improved } \\
\text { practices }\end{array}$} & \multicolumn{12}{|c|}{ Categories of respondents } \\
\hline & & \multicolumn{3}{|c|}{ Big (20) } & \multicolumn{3}{|c|}{ Medium (50) } & \multicolumn{3}{|c|}{ Small $(80)$} & \multicolumn{3}{|c|}{ Total $(\mathrm{N}=150)$} \\
\hline & & $\mathrm{f}$ & $\%$ & Rank & $\mathrm{f}$ & $\%$ & Rank & $\mathrm{f}$ & $\%$ & Rank & $\mathrm{f}$ & $\%$ & Rank \\
\hline 1 & Suitable varieties & 9 & 45.00 & IV & 29 & 58.00 & II & 43 & 53.75 & III & 81 & 54.00 & II \\
\hline 2 & Sowing operation & 7 & 35.00 & VI & 26 & 52.00 & IV & 47 & 58.75 & I & 80 & 53.33 & III \\
\hline 3 & $\begin{array}{l}\text { Fertilizer } \\
\text { management }\end{array}$ & 8 & 40.00 & $\mathrm{~V}$ & 30 & 60.00 & I & 39 & 48.75 & IV & 77 & 51.33 & IV \\
\hline 4 & $\begin{array}{l}\text { Irrigation } \\
\text { management }\end{array}$ & 12 & 60.00 & I & 25 & 50.00 & V & 38 & 47.50 & V & 75 & 50.00 & V \\
\hline 5 & Plant protection & 11 & 55.00 & II & 28 & 56.00 & III & 44 & 55.00 & II & 83 & 55.33 & I \\
\hline 6 & $\begin{array}{l}\text { Harvesting \& } \\
\text { marketing }\end{array}$ & 10 & 50.00 & III & 24 & 48.00 & VI & 39 & 48.75 & IV & 73 & 48.67 & VI \\
\hline \multicolumn{2}{|c|}{ Total } & 57 & 47.50 & - & 162 & 54.00 & - & 350 & 52.08 & - & 469 & 52.11 & _- \\
\hline
\end{tabular}

$\mathrm{F}=$ Frequency,$\%=$ Percentage

Table.3 Constraints responsible for the technology of rice cultivation $(\mathrm{N}=150)$

\begin{tabular}{|c|c|c|c|c|c|c|c|c|}
\hline $\begin{array}{l}\text { Improved } \\
\text { practices }\end{array}$ & $\begin{array}{l}\text { Lack of } \\
\text { knowledge }\end{array}$ & $\begin{array}{l}\text { Lack of } \\
\text { technical } \\
\text { guidance }\end{array}$ & $\begin{array}{l}\text { Lack of } \\
\text { availability } \\
\text { of inputs }\end{array}$ & $\begin{array}{l}\text { High } \\
\text { cost }\end{array}$ & $\begin{array}{l}\text { Lack of } \\
\text { money }\end{array}$ & $\begin{array}{l}\text { Low } \\
\text { rainfall }\end{array}$ & $\begin{array}{l}\text { Susceptibility } \\
\text { of disease }\end{array}$ & $\begin{array}{l}\text { Drought } \\
\text { proneness }\end{array}$ \\
\hline $\begin{array}{l}\text { 1.Suitable } \\
\text { varieties }\end{array}$ & 109 & 110 & 112 & 104 & 121 & 101 & 71 & 80 \\
\hline $\begin{array}{l}\text { 2.Field } \\
\text { preparation }\end{array}$ & 82 & 85 & 5 & 39 & 86 & 9 & 62 & 9 \\
\hline 3.Sowing time & 101 & 117 & 18 & - & 41 & 101 & 68 & 8 \\
\hline $\begin{array}{l}\text { 4. Method of } \\
\text { Sowing }\end{array}$ & 114 & 121 & - & 102 & 118 & 8 & 41 & 85 \\
\hline 5. Seed rate & 45 & 85 & 13 & 85 & 101 & 6 & - & 84 \\
\hline 6.Seed treatment & 106 & 112 & 108 & 41 & 101 & - & 16 & 90 \\
\hline 7.Soil treatment & 101 & 111 & 55 & - & 105 & - & 7 & - \\
\hline 8. Spacing & 103 & 109 & - & 102 & 105 & - & - & 89 \\
\hline $\begin{array}{l}\text { 9. Fertilizer } \\
\text { application }\end{array}$ & 76 & 107 & 50 & 43 & 123 & 90 & 73 & - \\
\hline $\begin{array}{l}\text { 10. Irrigation } \\
\text { management }\end{array}$ & 85 & 99 & 52 & 84 & 93 & 108 & 40 & 89 \\
\hline $\begin{array}{l}\text { 11. Weed } \\
\text { management }\end{array}$ & 117 & 125 & 109 & 98 & 123 & 86 & 35 & 80 \\
\hline $\begin{array}{l}\text { 12. Pest } \\
\text { management }\end{array}$ & 119 & 122 & 106 & 41 & 106 & 16 & 36 & 83 \\
\hline $\begin{array}{l}\text { 13. Disease } \\
\text { management }\end{array}$ & 118 & 124 & 107 & 102 & 121 & 15 & 38 & 96 \\
\hline 14. Harvesting & 91 & 97 & - & - & 91 & - & - & - \\
\hline 15. marketing & - & - & - & - & - & - & - & - \\
\hline Total & 1367 & 1524 & 735 & 841 & 1435 & 540 & 487 & 793 \\
\hline Percentage & 60.75 & 67.73 & 32.66 & 37.37 & 63.77 & 24.00 & 21.26 & 35.24 \\
\hline Rank & III & I & V & IV & II & VII & VIII & VI \\
\hline
\end{tabular}


Table.4 Management of sheath blight and blast disease of rice

\begin{tabular}{|c|c|c|c|c|c|c|c|c|c|}
\hline \multirow[t]{2}{*}{ SI.No. } & \multirow[t]{2}{*}{$\begin{array}{c}\text { Technological } \\
\text { option }\end{array}$} & \multicolumn{2}{|c|}{$\begin{array}{c}\text { Disease } \\
\text { intensity(\%) } \\
\text { before spray }\end{array}$} & \multicolumn{3}{|c|}{$\begin{array}{l}\text { Disease intensity (\%) } \\
\text { after } 2^{\text {nd }} \text { spray }\end{array}$} & \multirow[t]{2}{*}{$\begin{array}{l}\text { Yield } \\
\text { (Q/ha) }\end{array}$} & \multirow{2}{*}{$\begin{array}{l}\text { Increase } \\
\text { in yield } \\
\text { over } \\
\text { control } \\
(\%)\end{array}$} & \multirow[t]{2}{*}{$\begin{array}{l}\text { B:C } \\
\text { ratio }\end{array}$} \\
\hline & & $\begin{array}{l}\text { Leaf } \\
\text { blast }\end{array}$ & $\begin{array}{l}\text { Sheath } \\
\text { blight }\end{array}$ & $\begin{array}{l}\text { Leaf } \\
\text { blast }\end{array}$ & $\begin{array}{l}\text { Sheath } \\
\text { blight }\end{array}$ & $\begin{array}{c}\text { Panicle } \\
\text { blast }\end{array}$ & & & \\
\hline 1. & $\begin{array}{l}\text { TO:1-Farmer's } \\
\text { practice }\end{array}$ & $\begin{array}{c}10.43 \\
(18.44)\end{array}$ & $\begin{array}{c}13.55 \\
(21.08)\end{array}$ & $\begin{array}{c}12.45 \\
(20.16)\end{array}$ & $\begin{array}{c}20.78 \\
(26.06)\end{array}$ & $\begin{array}{c}14.37 \\
(21.71)\end{array}$ & 30.4 & - & $\begin{array}{c}1: \\
0.98\end{array}$ \\
\hline 2. & 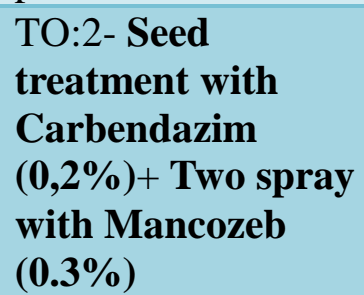 & $\begin{array}{c}6.22 \\
(14.26)\end{array}$ & $\begin{array}{c}12.28 \\
(20.05)\end{array}$ & $\begin{array}{c}8.25 \\
(16.44)\end{array}$ & $\begin{array}{c}12.77 \\
(20.45)\end{array}$ & $\begin{array}{c}10.49 \\
(18.50)\end{array}$ & 32.5 & 6.4 & 1: 1.3 \\
\hline 3. & 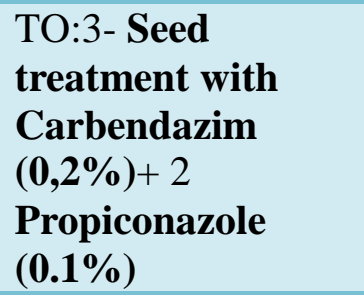 & $\begin{array}{c}3.84 \\
(11.17)\end{array}$ & $\begin{array}{c}9.56 \\
(17.70)\end{array}$ & $\begin{array}{c}5.66 \\
(13.57)\end{array}$ & $\begin{array}{c}11.72 \\
(1959)\end{array}$ & $\begin{array}{c}7.84 \\
(16.04)\end{array}$ & 33.8 & 11.1 & $1: 1.5$ \\
\hline 4. & $\begin{array}{l}\text { TO:4- } 1^{\text {st }} \text { spray } \\
\text { with Carbendazim } \\
(0.2 \%) \& 2^{\text {nd }} \text { spray } \\
\text { with Propiconazole } \\
(0.1 \%)\end{array}$ & $\begin{array}{c}2.54 \\
(9.11)\end{array}$ & $\begin{array}{c}7.12 \\
(15.24)\end{array}$ & $\begin{array}{c}3.12 \\
(10.08)\end{array}$ & $\begin{array}{c}9.68 \\
(17.81)\end{array}$ & $\begin{array}{c}4.20 \\
(11.68)\end{array}$ & 34.4 & 13.1 & 1: 1.8 \\
\hline & $\mathrm{CD}$ at $5 \%$ & 0.76 & 1.84 & 2.12 & 0.98 & 2.76 & 0.51 & - & \\
\hline
\end{tabular}

* Figures in parenthesis are angular transformed values

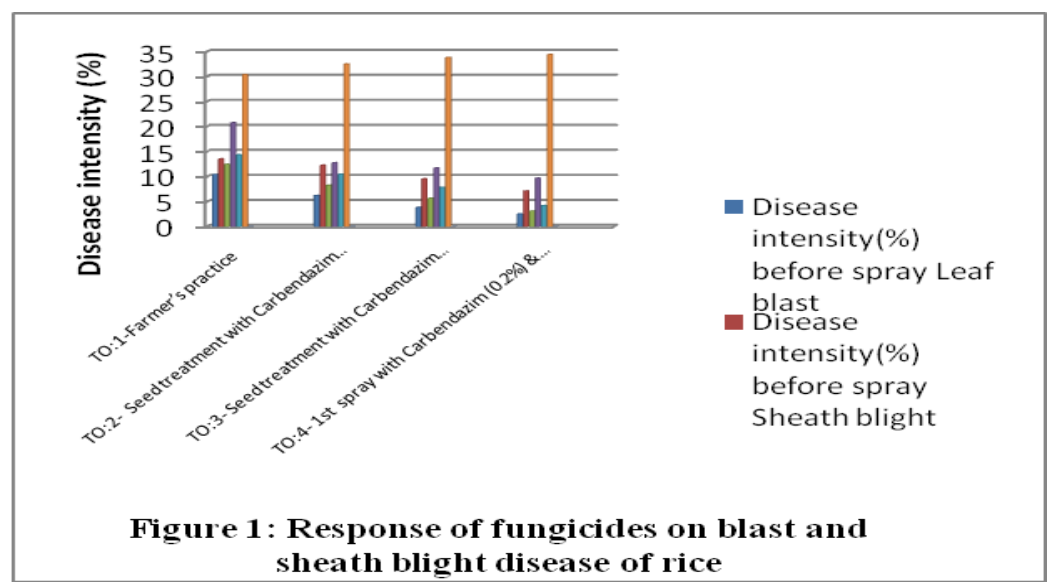

The minimum yields of $30.40 \mathrm{q} / \mathrm{h}$ recorded in control plots (TO1). Singh and Sunder, 2015, reported that, use of combi product Trifloxistrobin 25\% + Tebuconazole @50\% at $0.4 \mathrm{~g} / \mathrm{l}$ reduced the blast incidence from 23.75 to $9.18 \%$ along with significant increase in grain yield. Trifloxistrobin $25 \%+$ Tebuconazole @ 50\% and Propiconazole have 
been found highly effective in managing sheath blight of rice (Hunjan et al., 2011). Thus the result indicated that $1^{\text {st }}$ spray with Carbendazim $(0.2 \%) \quad \& \quad 2^{\text {nd }}$ spray with Propiconazole $(0.1 \%)$ was effective in reducing incidence of both blast and sheath blight diseases and increased the grain yields. These results are well collaborated with the earlier findings (Rao, et al., 2012).

In conclusion the wider gap in non adoption of new technology by rice grower was observed. A large number of research findings are available but all of them have not reached to farmers which ultimately caused wide gap between available scientific knowledge and its practical adoption. These gaps are responsible for low production of rice. $1^{\text {st }}$ spray with Carbendazim $(0.2 \%) \& 2^{\text {nd }}$ spray with Propiconazole $(0.1 \%)$ was effective in reducing incidence of both blast and sheath blight diseases and increased the grain yields.

Although losses due to plant diseases may be reduced by the use of disease resistance cultivars, crop rotation or sanitation practices, fungicides are often essential to maximize crop yields. Fungicides can play an important role in ensuring crop health security by managing devastating diseases in agricultural crops. Fungicides play important role in improving food quality and they also contribute to food safety by controlling many fungi that produce mycotoxins such as aflotoxins, ergot toxins, Fusarium toxins, patulin and tenuazonic acid (Knight et al., 1997). Fungicides are now well considered to be the second line of defense in plant disease control after disease resistance (Thind, 2015). It is expected that, fungicides will continue to play a role in disease management programs, especially in intensive production systems. However, to maintain their effectiveness and to minimize their effect on human health and on the environment, they should be used in a rational and informed way.

\section{References}

Anonymous 2002. Standers Evaluation system for Rice, fifth edition, November 2002, INGER, Genetic resources center, IRRI, P.O. Box933, 1099, Manila, Philippines, p. 56.

Distahporn, S. 1994. Current rice blast epidemics and their management in Thailand. In: Rice blast disease. $C A B$, International, Wallingford, $U K, \mathrm{pp}$ 331-342.

Hare S, Neate S, Dijst G (eds) Rhizoctoniasps, taxonomy, molecular biology, ecology, pathology and disease control, Kluwer, Dordrecht. pp. 237-244.

Hunjan, M. S., Lore, J. S. Pannu, P. P. S. and Thind, T. S. 2011. Performance of some new fungicides against sheath blight and brown spot of rice. $P l$. Dis. Res. 26: 61-67.

Knight, S. C., Anthony, V. M., Brady, A. M., Greenland, A. J., Heaney, S. P., Murray, D. C., Powell, K. A., Schulz, M. A., Spinks, C. A. Worthington, P. A. and Youle, D. 1997. Rationale and perspectives on the development of fungicides. Ann. Rev. Phytopat. 35: 349-372.

Lalithakumari, D. and Annamalai, P. 1990. Edifenphos resistance in Pyricularia oryzae and Drechslera oryzae. In: Proc I international symposium on Managing Resistance to Agrochemicals. pp. 249-263.

Narayanaprasad Jagadeesh, B. R., Shivakumarum, G. B., Prasad, P. S., Sudarshan, G. K. and Sunil kumar, N. 2011. Studies on the nature and properties of sheath rot causing seed borne pathogen on rice. Int J. Sci. Nat. 2: 317-320.

Rao, N. Ravindrakumar and Ananadraj, M. 2012. Management of Leaf spot of turmeric incited by Colletotrichum 
capsici through fungicides. J. Spices Aromatc crops. 21: 151-154.

Savary, S. and Mew, T. W. 1996. Analysing crop losses due to Rhizoctonia solani: rice sheathblight, a case study. In: Sneh, Javali

Sharma S., Singh A.K. and Kumar S.(2007). Studies on the socio-economic and technological factors responsible for low productivity of rice crop. J.Farming System Research \& Development 13(1): 117-121.

Singh, R. and Sunder, S. 2015. Identification of sources of resistance to blast and false smut of rice and their management with fungicides. J. Mycol. Pl. Pathol. 45(1): 55-59.

Thind, B. S. 2002. Plant Disease Scenario in Punjab and Himachal Pradesh, In:
Proceedings of the training course on integrated approaches in Plant Disease management for sustainable Agriculture. Thind, B.S.,

Thind, B. S. 2015. Relevance of fungicides in the present day crop protection and the way ahead. J. Mycol. Pl. Pathol. 45(1): 4-12.

Wheeler, B. E. J. 1969. An Introduction to Plant Diseases, John Wiley and Sons Ltd. London, p. 301.

Zhong, T. W., Zhang Wei, Ou Zeng Qi, Li Cheng Wen, Zhou Guan Jun, Wang Zhi Kun and Yin Li Li. 2007. Analyses of temporal development and losses due to sheath blight of rice (Rhizoctonia solani) Agric. Sci. China. 6: 1074-1081.

\section{How to cite this article:}

Rajiv Kumar. 2020. Management of Sheath Blight and Blast Disease of Rice. Int.J.Curr.Microbiol.App.Sci. 9(09): 1659-1665. doi: https://doi.org/10.20546/ijcmas.2020.909.206 